\title{
PENINGKATAN HASIL BELAJAR KIMIA SISWA MELALUI MODEL PEMBELAJARAN KOOPERATIF TIPE THINK PAIR SHARE (TPS) DI SMAN 92 JAKARTA
}

\author{
Yohana Junita ${ }^{1}$, Leony Sanga Lamsari Purba ${ }^{2}$ \\ yohanajunita51@gmail.com \\ Universitas Kristen Indonesia
}

\begin{abstract}
This research is a pure experimental study with a pre-test and post-test only control design. The population includes all students of class XI MIPA SMAN 92 Jakarta Semester I Academic Year 2018/2019. The study sample consisted of two classes with a sample size of 58 students determined by purposive sampling. The research instrument is a test question. Hypothesis test conducted by parametric test is testing paired samples $t$ test at a significant level of 0.05 with the help of SPSS 23 for windows. The results of this study obtained $t$ count of 36,286 and a significant value of 0.00. Based on data analysis and hypothesis testing carried out obtained that: (1) There is an increase in student chemistry learning outcomes through cooperative learning models think pair share at SMAN 92 Jakarta. (2) Increasing students' chemistry learning outcomes by using the cooperative learning model think pair share of 0.7 in the N-gain category, when compared to the conventional model of 0.67.
\end{abstract}

Keywords: improvement, learning model, learning outcomes, and Think pair share

\begin{abstract}
ABSTRAK
Penelitian ini merupakan penelitian eksperimen murni dengan desain pre-test and post-test only control. Populasi meliputi seluruh siswa kelas XI MIPA SMAN 92 Jakarta Semester I Tahun Pelajaran 2018/2019. Sampel penelitian terdiri dari dua kelas dengan jumlah sampel 58 siswa yang ditentukan dengan purposive sampling. Instrumen penelitian berupa tes soal. Uji Hipotesis yang dilakukan dengan uji parametrik yaitu uji paired samples $t$ test pada taraf signifikan 0,05 dengan bantuan SPSS 23 for windows. Hasil penelitian ini memperoleh thitung sebesar 36,286 dan nilai signifikan 0,00. Berdasarkan analisis data dan uji hipotesis yang dilakukan diperoleh bahwa: (1) Terdapat peningkatan hasil belajar kimia siswa melalui model pembelajaran kooperatif tipe think pair share di SMAN 92 Jakarta. (2) Peningkatan hasil belajar kimia siswa dengan meggunakan model pembelajaran kooperatif tipe think pair share sebesar 0,7 dalam kategori $\mathrm{N}$-gain, bila dibandingkan dengan model konvensional sebesar 0,67.

Kata Kunci: peningkatan, model pembelajaran, hasil belajar dan think pair share
\end{abstract}




\section{PENDAHULUAN}

Pendidikan berperan penting dalam menghasilkan lulusan yang berkompeten, dan mampu bersaing di dunia kerja. Untuk menghasilkan lulusan yang berkompeten, pendidikan harus menyiapkan peserta didiknya mencapai hasil pembelajaran yang baik. DKI Jakarta sebagai salah satu pelaksana pendidikan, menjadi gambaran kompetensi lulusan dengan nilai Ujian Nasional (UN) mata pelajaran kimia yang masih rendah.Nilai rata-rata UN yang terendah yaitu 30.0 pada mata pelajaran kimia di bandingkan dengan nilai UN pada mata pelajaran fisika 42.50, biologi 40.00, matematika 52.80 (Kemendikbud, 2017).

Dari keseluruhan nilai UN di DKI Jakarta yang juga salah satunya memiliki nilai ratarata UN pada mata pelajaran kimia yang rendah bahkan mengalami penurunan 3 tahun secara berturut turut adalah SMAN 92 Jakarta. Hal ini terlihat pada tahun ajaran 2014/2015 rata-rata nilai UN pada mata pelajaran kimia mencapai 62.55 , pada tahun ajaran 2015/2016 mencapai nilai rata-rata UN 57.14, dan pada tahun ajaran 2016/2017 hanya mencapai 48.56. Rendahnya nilai UN membuktikan hasil belajar dan pemahaman konsep kimia masih rendah.

Berdasarkan hasil wawancara pada tanggal 12 Maret 2018 yang dilakukan peneliti dengan guru bidang studi kimia dan beberapa siswa kelas X-XI di SMAN 92 Jakarta, minat siswa terhadap pembelajaran kimia sudah tinggi, terlihat dari meningkatnya mata pelajaran pilihan yang diminati pada saat ujian nasional meningkat dua kali lipat dari sebelumnya. Data ini diperoleh dari jumlah siswa yang memilih UN pada mata pelajaran kimia di tahun sebelumnya hanya 1 kelas, namun tahun ini menjadi 2 kelas. Dengan minat siswa yang sudah tinggi, hal ini sesuai dengan hasil belajar kimia di raport yang diperoleh siswa pada hasil ke empat kelas sewaktu dikelas X, yaitu X MIPA 1 sampai dengan X MIPA 4 tergolong menengah keatas dengan rata-rata nilai mencapai kriteria ketuntasan minimum (KKM). Tujuan dari pembelajaran tidak semata-mata untuk memperoleh hasil belajar, namun keberhasilan proses pembelajaran tentunya akan berdampak terhadap hasil belajar. Agar proses pembelajaran dapat berjalan sesuai dengan yang direncanakan maka pendidik harus menciptakan iklim belajar yang baik.

Berdasarkan hasil wawancara dengan guru bidang studi, kendala yang dialami siswa selama proses pembelajaran berlangsung adalah kurangnya komunikasi, kerjasama dan empati pada diri siswa. Siswa yang kurang berinteraksi dan siswa yang masih kurang berani untuk menyampaikan pendapat selama proses pembelajaran mengakibatkan keterlambatan dalam memahami materi tersebut. Guru masih belum bisa memprediksi nilai siswa karena terkadang siswa bisa mencapai KKM namun di materi yang lain siswa juga bisa tidak mencapai KKM. Dengan materi hidrokarbon, siswa dilatih lagi untuk mampu menganalisis soal sehingga diharapkan terjadi peningkatan hasil belajar. 
Berdasarkan kondisi tersebut terdapat berbagai upaya yang dapat dilakukan misalnya guru diminta untuk lebih kreatif dengan menciptakan iklim belajar yang lebih hidup, aktif, efektif, dan menyenangkan dengan membimbing siswa untuk melakukan diskusi sehingga proses belajar mengajar dapat melibatkan peserta didik secara langsung. Dengan memberi siswa kesempatan dalam berkomunikasi, bekerjasama, saling empati, dan saling berinteraksi, maka setiap siswa berani untuk mengemukakan pendapatnya selama proses pembelajaran berlangsung sehingga mampu meningkatkan sosial mereka. Melalui kendala siswa dalam pembelajaran, model pembelajaran kooperatif tipe think pair share (TPS) sangat di sarankan untuk digunakan selama proses pembelajaran.

Model pembelajaran kooperatif tipe think pair share mampu membuat suasana pembelajaran menjadi menyenangkan dan lebih efektif dengan mengganti pola diskusi. Model pembelajaran ini juga memberi siswa waktu untuk berpikir, sehingga meningkatkan respon siswa dalam setiap pertanyaan yang diajukan oleh guru, melatih siswa untuk berani berpendapat dan menghargai pendapat teman kelompoknya (Shoimin, 2014). Model Pembelajaran TPS ini mampu mendukung pembelajaran kimia pada materi hidrokarbon. Hal ini disebabkan materi hidrokarbon yang membuat siswa lebih terbuka lagi dalam berpikir, sehingga bisa memecahkan kesulitan siswa dalam mengerjakan soal melalui aktivitas siswa selama proses pembelajaran berlangsung.

Materi hidrokarbon adalah materi dasar di kelas XI, karena siswa di kelas XI belum pernah belajar materi hidrokarbon, dengan menggunakan model pembelajaran kooperatif tipe think pair share, pada tahap think maka siswa di stimulasi atau diberikan pertanyaan terlebih dahulu terkait hidrokarbon agar siswa dapat berpikir sendiri terlebih dahulu mengenai pertanyaan yang diajukan. Lalu tahap pair setelah siswa menjawab sendiri, siswa berpasangan dengan teman yang sudah ditentukan. Dengan tahap pair siswa dilatih untuk berkomunikasi dengan baik dengan siapapun teman kelompoknya yang sudah ditentukan guru, siswa juga dilatih untuk bekerjasama dengan baik selama proses diskusi untuk memperoleh jawaban yang tepat, terakhir pada tahap share, masing-masing kelompok sudah memiliki jawaban mengenai soal yang sudah didiskusikan, lalu guru dengan secara acak menunjuk kelompok siswa untuk mempresentasikan. Kelompok yang ditunjuk, mempresentasikan jawaban yang sudah mereka diskusikan. Kelompok lain yang tidak mempresentasikan, dilatih untuk berempati dengan mendengarkan kelompok yang sedang presentasi. Namun, kelompok lain juga bisa mengajukan pertanyaan kepada kelompok yang sedang presentasi, atau kelompok lain juga bisa memberikan tanggapan kepada kelompok yang sedang presentasi namun tidak bisa menjawab pertanyaan dari kelompok lainnya. 
Peneliti berharap adanya peningkatan hasil belajar dengan menggunakan model pembelajaran kooperatif tipe TPS terhadap materi hidrokarbon.

Penelitian yang terdahulu dengan menggunakan model pembelajaran kooperatif tipe think pair share yang mampu meningkatkan hasil belajar kimia siswa dengan materi karakteristik teori maupun perhitungan diantaranya (Fajaryanti, dkk, 2014) yang berjudul "Penggunaan model pembelajaran kooperatif tipe think pair share (TPS) pada pokok bahasan struktur atom untuk meningkatkan hasil belajar siswa kelas X SMA Negeri 2 Palu". Yang menyimpulkan bahwa hasil belajar siswa dengan menggunakan model pembelajaran tipe TPS lebih tinggi dari pada hasil belajar siswa yang tanpa menggunakan model pembelajaran kooperatif tipe TPS. Selain itu oleh Suhardi (2018) yang berjudul "Penerapan model pembelajaran kooperatif tipe Think Pair Share (TPS) untuk meningkatkan hasil belajar peserta didik pada mata pelajaran kimia tentang termokimia di kelas XI MIPA-2 SMA Negeri 7 Kota bogor" menyimpulkan bahwa penggunaan model pembelajaran kooperatif tipe TPS (Think Pair Share) yang disesuaikan dengan materi pembelajaran dapat menciptakan situasi belajar yang menyenangkan sehingga terjadi peningkatan hasil belajar peseta didik dengan nilai rata-rata 76.07 pada siklus 1 dan 83.03 pada siklus 2. Berdasarkan latar belakang di atas, maka penting bagi peneliti untuk melakukan penelitian yang berjudul "Peningkatan Hasil Belajar Kimia Siswa Melalui Model Pembelajaran Kooperatif Tipe Think Pair Share (TPS) di SMAN 92 Jakarta".

Belajar adalah proses yang dilakukan seseorang untuk mendapatkan tingkah laku baik dari pengalamannya sendiri maupun interaksi dengan lingkungannya (Slameto, 2010). Rusmono (2017) menjelaskan belajar merupakan proses perbahan tingkah laku individu sebagai hasil dari pengalamannya dalam berinteraksi dengan lingkungan. Menurut Rusman (2017) belajar pada hakikatnya adalah interaksi terhadap semua situasi yang ada di sekitar individu siswa. Menurut Slameto (2010) perubahan yang dimaksud antara: (1) Perubahan terjadi secara sadar. Hal ini menunjukan bahwa seseorang yang belajar akan menyadari terjadinya perubahan dalam dirinya. (2) Bersifat kontinu dan fungsional. Siswa juga harus memiliki perubahan yang terjadi dalam diri siswa secara berkesimbungan atau tidak statis. (3) Perubahan dalam belajar bersifat positif dan aktif. Dalam belajar, perubahan-perubahan siswa akan bertambah untuk mencapai sesuatu yang lebih baik dari sebelumnya. (4) Perubahan dalam belajar bertujuan atau terarah. Hal ini menunjukan untuk mencapai sebuah tujuan maka diperlukan perubahan tingkah laku. Dari penjelasan beberapa ahli, dapat diambil kesimpulan bahwa belajar adalah proses perubahan tingkah laku setiap individu melalui interaksi sosialnya. Sedangkan pembelajaran adalah rangkaian selama proses belajar mengajar berlangsung, yang diakhiri dengan perubahan tingkah laku. 
Pembelajaran pada hakikatnya ialah usaha seorang guru membelajarkan siswanya dengan mengarahkan interaksi siswa pada sumber belajar lainnya dalam mencapai tujuan yang diharapkan dan keberhasilan pembelajaran.Dari makna ini terlihat bawah pembelajaran adalah interaksi dua arah baik dari guru maupun siswa (Emda, 2014). Adapun pengertian pembelajaran menurut Surraya dkk, (2014) pembelajaran merupakan kegiatan yang mempunyai tujuan dengan membelajarkan siswa untuk mencapai kompetensi yang diinginkan, yang dipengaruhi beberapa faktor seperti guru, siswa, sarana, media, serta lingkungannya. Guru pun berperan penting sebagai motivator dan fasilitator dalam mengembangkan minat siswa dalam mencari ilmu pengetahuannya secara mandiri. Menurut Dimyati (2015), pembelajaran merupakan proses interaksi peserta didik dengan pendidik dan sumber belajar pada suatu lingkungan belajar. Menurut Ristiyani dan Bahriah (2016) materi pelajaran kimia di SMA/MA banyak berisi konsep-konsep yang cukup sulit untuk dipahami siswa, karena menyangkut reaksi-reaksi kimia dan hitungan-hitungan serta menyangkut konsep-konsep yang bersifat abstrak dan dianggap oleh siswa merupakan materi yang relatif baru.

Sekolah dengan input siswa yang unggulan mungkin tidak akan terpengaruh dengan permasalahan kurang dikenalnya pelajaran kimia, karena dilihat dari sisi inteligensi siswanya yang tergolong baik sehingga guru tidak akan mengalami kesulitan dalam menyampaikan materi pelajaran kimia. Akan tetapi berbanding terbalik dengan input siswa yang tergolong kurang unggul, maka ini akan menjadi tugas yang berat bagi guru kimia di sekolah tersebut untuk memberikan pemahaman yang lebih bagi para siswanya. Berdasarkan definisi tersebut disimpulkan bahwa pembelajaran kimia adalah suatu kegiatan yang dilakukan oleh guru dengan bahan ajar materi kimia.Kemudian dilaksanakan dengan menarik, dengan menggunakan metode pembelajaran yang tepat sehingga siswa memperoleh berbagai pengalaman di bidang kimia sesuai dengan standar isi. Sehingga timbul perubahan dalam pengetahuan, pemahaman, keterampilan. Serta nilai sikap dalam diri siswa terhadap kimia.Hasil belajar terlihat pada hasil-hasil yang dicapai siswa dengan kriteria tertentu (Emda, 2014).

Adapun pengertian hasil belajar menurut Suhardi (2018) hasil belajar adalah hasil akhir yang dipengaruhi beberapa faktor antara lain peserta didik, guru, materi pelajaran, model pembelajaran dan lingkungan. Apabila peserta didik kurang menguasai konsep pada materi pelajaran, guru kurang memotivasi siswa, dan kurang mampu menggunakan media belajar dan kurang tepat memilih pendekatan ataupun model pembelajaran yang sesuai untuk setiap materi, hal ini membuat siswa menjadi tidak tertarik pada pelajaran tersebut, proses pembelajaran menjadi jenuh dan membosankan, sehingga siswa sulit memahami 
materi yang diterima dan hasil pembelajaran siswa pun kurang baik. Menurut sudjana (2009) hasil belajar adalah proses pemberian nilai terhadap hasil belajar yang dicapai oleh peserta didik dengan kriteria tertentu dengan objek yang dinilai. Hal lain menurut sudjana (2009) hasil belajar mencakup tiga ranah yakni ranah kognitif, afektif, dan psikomotoris.

Ranah Kognitif meliputi tipe hasil belajar antara lain pengetahuan, pemahaman, analisis, sintesis, dan evaluasi. Ranah Afektif meliputi receiving, responding, valuing, organisasi dan karakteristik nilai. Ranah Psikomotoris meliputi gerak reflex, keterampilan pada gerakan dasar, kemampuan perseptual, dan kemampuan yang berkenaan dengan komunikasi non-secursive.Alat penilaian hasil belajar ialah tes, baik tes uraian (esai) maupun tes objektif. Dapat kita Tarik kesimpulan bahwa hasil belajar adalah nilai akhir yang dicapai setelah proses pembelajaran dengan kriteria tertentu.

Menurut Emda (2014), pembelajaran kooperatif merupakan suatu model pembelajaran yang digunakan untuk mewujudkan kegiatan belajar mengajar yang berpusat pada siswa (studend oriented), terutama untuk mengatasi permasalahan yang ditemukan guru dalam mengaktifkan siswa, yang tidak dapat bekerjasama dengan orang lain dan siswa yang agresif dan tidak peduli pada yang lain. Pada model cooperative learning siswa diberi kesempatan untuk berkomunikasi dan berinteraksi sosial dengan temannya untuk mencapai tujuan pembelajaran, sementara guru bertindak sebagai motivator dan fasilitator aktivitas siswa. Artinya dalam pembelajaran ini kegiatan aktif dengan pengetahuan dibangun sendiri oleh siswa dan mereka bertanggung jawab atas hasil pembelajarannya.Model pembelajaran kooperatif tipe Think Pair Share adalah model pembelajaran yang memberikan kesempatan kepada siswa untuk bekerjasama dengan orang lain. Dalam hal ini guru berperang untuk membimbing siswa melakukan diskusi agar tercipta suasana pembelajaran yang lebih hidup, aktif, kreatif, efektif, dan menyenangkan. Dengan kata lain, model pembelajaran kooperatif tipe TPS dirancang untuk mempengaruhi pola interaksi siswa, dan cara yang efektif untuk mengganti suasana pola diskusi kelas (Emda, 2014).

Think Pair Share adalah model pembelajaran kooperatif yang efektif untuk membuat variasi suasana pola diskusi. Prosedur yang digunakan dalam model think pair share dapat memberi siswa lebih banyak waktu berpikir, merespon dan saling membantu (Trianto, 2010). Menurut Shoimin (2014) Think Pair Share ialah model pembelajaran kooperatif yang memberikan siswa waktu untuk berpikir, merespon, dan saling membantu satu sama lain. Dengan memberikan waktu untuk berpikir, menjadi faktor kuat untuk meningkatkan kemampuan siswa dalam merespon pertanyaan yang diajukan oleh guru. Pembelajaran ini relatif sederhana karena tidak menyita waktu dalam mengelompokan siswa.pembelajaran ini juga melatih setiap siswa untuk berani berpendapat dan menghargai pendapat temannya. 
Jadi siswa diharpakan mampu bekerja sama, saling membutuhkan dalam keberhasilan kelompoknya. Berdasarkan penjelasan di atas, siswa dapat mengembangkan keterampilan sosialnya, dalam hal bertanya kepada teman sekelompoknya ketika ada materi yang tidak dimengerti, atau bertanya pada saat diskusi kelas berlangsung. Siswa juga terampil dalam hal bekerja sama dengan teman satu kelompoknya, siswa juga diajarkan menjadi pendengar yang baik dalam hal mendengarkan guru maupun pendapat dari teman kelompok lain yang berbeda pendapat pada saat presentasi didepan kelas. Tahap-tahap model pembelajaran Think Pair Share (TPS) antara lain:

1. Tahap satu, think (berpikir)

Guru memberikan sebuah pertanyaan terbuka yang terkait dengan materi pelajaran yang memungkinkan setiap siswa untuk menjawab dengan berbagai jawaban.

2. Tahap dua, pair (berpasangan)

Guru meminta siswa untuk berpasangan dan mulai memikirkan pertanyaan yang sudah diberikan oleh guru. Lamanya waktu ditetapkan berdasarkan pemahaman guru terhadap siswa, sifat pertanyaan yang diajukan, dan jadwal pembelajarannya. Siswa juga disarankan untuk menulis jawaban dari pertanyaan yang diberikan.

3. Tahap ketiga, share (berbagi)

Guru meminta salah satu dari kelompok yang ditunjuk atau bersama dengan pasangannya untuk melaporkan hasil diskusi mereka ke seluruh kelas. Siswa yang lain mendengarkan, dan memberikan tanggapan mengenai hasil diskusi dari teman yang sedang mempresentasikan di depan kelas. Kelebihan dari TPS antara lain:

1. TPS mudah diterapkan diberbagai jenjang pendidikan dan dalam setiap kesempatan.

2. Menyediakan waktu berpikir untuk meningkatkan kualitas respon setiap siswa.

3. Siswa menjadi lebih aktif dalam berpikir mengenai konsep dalam nama pelajaran.

4. Siswa lebih memahami konsep mata pelajaran selama diskusi

5. Siswa dapat belajar dari siswa lain

6. Setiap siswa dalam kelompoknya mempunyai kesempatan untuk mengemukakan pendapat dan berbagi hasil yang sudah didiskusikan.

Shoimin (2014) mengatakan model ini memberikan kesempatan kepada peserta didik untuk berpikir, bekerjasama dengan kelompoknya, dan berbagi hasil diskusi dengan berani mengemukakan pendapat. Keunggulan lain dari TPS menurut suhardi (2018) model pembelajaran yang mengoptimalkan partisipasi setiap peserta didik dan memberi kesempatan kepada mereka untuk berani mengemukakan pendapat sendiri dengan berbagai argument yang didasari pengetahuan. 


\section{METODOLOGI PENELITIAN}

Penelitian ini dilaksanakan kepada siswa-siswi kelas XI MIPA 1 dan XI MIPA 3 SMA Negeri 92 Jakarta dengan menggunakan model pembelajaran kooperatif tipe think pair share. Dengan teknik purposive sampling, diperoleh sebanyak 58 siswa yang dijadikan responden.Variabel penelitian ini terdiri atas variabel bebas dan variabel terikat. Adapun Variabel bebas (independen) dalam penelitian ini adalah model pembelajaran think pair share dan variabel terikat (dependen) dalam penelitian ini adalah hasil belajar kimia siswa kelas XI MIPA 1 dan XI MIPA 3.

Desain penelitian yang digunakan dalam penelitian ini adalah pretest-posttest control group design Seperti tampak pada table di bawah.

\begin{tabular}{llll}
\hline Kelompok & Pretes & Perlakuan & Postes \\
\hline Eksperimen & $\mathrm{O}_{1}$ & $\mathrm{X}$ & $\mathrm{O}_{2}$ \\
\hline Kontrol & $\mathrm{O}_{1}$ & & $\mathrm{O}_{2}$ \\
\hline
\end{tabular}

Penelitian ini menggunakan metode tes. Tes ini berupa pretest dan posttest sebanyak 10 soal dalam bentuk tes esai. Instrumen penelitian ini disusun berdasarkan konsep dan landasan teori, dan di uji cobakan pada responden.

\section{Hasil Penelitian dan Pembahasan}

Hasil penilitian peningkatan hasil belajar kimia siswa di SMAN 92 Jakarta dengan menggunakan model pembelajaran kooperatiftipe TPS dapat terlihat pada rangkuman deskripsi data pada tabel. Data pretest kelas control dan kelas eksperimen antara lain :

\section{Data Pretest Kelas Kontrol dan Kelas Eksperimen}

\begin{tabular}{|l|l|l|l|lr|lr|lr|rr|l|l|l|l|l|l|}
\hline & \multicolumn{2}{|c|}{$\mathrm{N}$} & Range & Minimum & Maximum & S u m & M e a & $\mathrm{n}$ & Std. Deviation & Variance \\
\cline { 2 - 11 } & Statistic & Statistic & Statistic & Statistic & Statistic & Statistic & Std. Error & Statistic & Statistic \\
\hline Pretest Kontrol & 3 & 0 & 3 & 0 & 1 & 2 & 4 & 2 & 7 & 9 & 6 & 26.53 & 1.784 & 9.769 & 95.430 \\
PretestEksperimen & 2 & 8 & 3 & 0 & 1 & 2 & 4 & 2 & 7 & 2 & 0 & 25.71 & 1.804 & 9.548 & 91.175 \\
Valid N (listwise) & 2 & 8 & & & & & & & & & & & & \\
\hline
\end{tabular}

\section{Data Posttest Kelas Kontrol dan Kelas Eksperimen}
| D
s
r i
p $t$

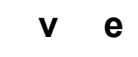
$S \mathrm{t}$
a

i s $t$ i c s




\begin{tabular}{|c|c|c|c|c|c|c|c|c|c|}
\hline & $\begin{array}{c}\mathrm{N} \\
\text { Statistic }\end{array}$ & $\begin{array}{l}\text { Range } \\
\text { Statistic }\end{array}$ & $\begin{array}{l}\text { Minimum } \\
\text { Statistic }\end{array}$ & $\begin{array}{l}\text { Maximum } \\
\text { Statistic }\end{array}$ & $\begin{array}{l}\text { S u m } \\
\text { Statistic }\end{array}$ & $\begin{array}{l}\text { M e } \\
\text { Statistic }\end{array}$ & $\begin{array}{l}\text { a } \mathrm{n} \\
\text { Std. Erro" }\end{array}$ & $\begin{array}{l}\text { Std. Deviation } \\
\text { Statistic }\end{array}$ & $\begin{array}{l}\text { Variance } \\
\text { Statistic }\end{array}$ \\
\hline Posttest Kontrol & 3 & 7 & 1 & 8 & 2472 & 68.67 & 3.053 & 18.318 & 335.543 \\
\hline Posttest Eksperimen & 3 & 7 & 1 & 9 & 2332 & 68.59 & 3.661 & 21.346 & 455.643 \\
\hline Valid N (listwise) & 34 & & & & & & & & \\
\hline
\end{tabular}

Pengujian persyaratan normalitas data menggunakan teknik uji Lilliefors dan persyaratan homogenitas varians populasi menggunakan teknik seperti tabel berikut ini.

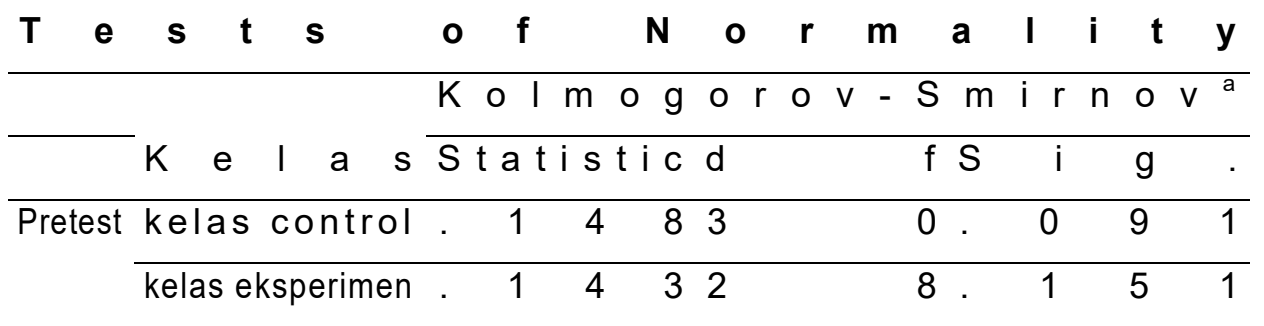

Tabel Hasil uji hipotesis paired-sample t test

\begin{tabular}{|c|c|c|c|c|c|c|c|c|c|c|}
\hline & \multicolumn{5}{|c|}{$P$ a } & \multirow[b]{3}{*}{$\mathrm{T}$} & \multirow[b]{3}{*}{ d } & \multirow[b]{3}{*}{$f$} & \multirow[b]{3}{*}{ Sig. (2-tailed) } \\
\hline & & \multirow[b]{2}{*}{ Mean } & \multirow[b]{2}{*}{ Std. Deviation } & \multirow[b]{2}{*}{ Std. Error Mean } & \multicolumn{2}{|c|}{ 95\% Confidence Interval of the Difference } & & & & \\
\hline & & & & & L o w e r & U p p e r & & & & \\
\hline Pair 1 & Posttest - Pretest & 50.966 & 10.697 & 1.405 & 48.153 & 53.778 & 36.286 & 5 & 7 & 000 \\
\hline
\end{tabular}

Uji Hipotesis untuk peningkatan data pretest dan posttest kelas kontrol dan kelas eksperimen ditemukan $t_{\text {hitung }}$ sebesar 36,286 dan tabel $\alpha / 2(d f=57)$ maka $t_{\text {tabel }}=2.00247$. Berdasarkan data tersebut $t_{\text {hitung }}(36,286)>t_{\text {tabel }}(2.00247)$ dan berdasarkan nilai sig. diperoleh p-value untuk kelas kontrol dan kelas eksperimen $=0,00<0,05$. Berdasarkan kedua hasil tersebut maka $\mathrm{Ha}$ diterima dan $\mathrm{H}_{0}$ ditolak, sehingga dapat disimpulkan bahwa terdapat peningkatan setelah dilakukan atau diberi perlakuan dengan model pembelajaran kooperatif tipe think pair share (TPS).

Adapun untuk melihat berapa besar peningkatan nya dilakukan dengan uji gain yang diperoleh pada table berikut ini.

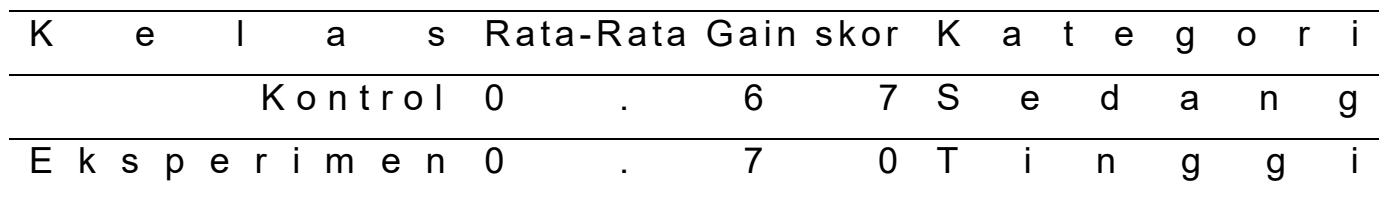


Nilai gain yang diperoleh kelas kontrol lebih rendah dari nilai gain yang diperoleh kelas eksperimen. Meskipun selisih nilai gain peningkatan dari kelas kontrol dan kelas eksperimen hanya 0,03 namun ini juga menunjukan peningkatan hasil belajar ketika diberi perlakuan selama proses pembelajaran di kelas eksperimen dengan model pembelajaran kooperatif tipe think pair share (TPS).

Dari kedua kelas yaitu kelas kontrol dan kelas eksperimen, diperoleh nilai hasil pretest dengan nilai terendah sebesar 12 dan nilai tertinggi sebesar 42, dengan nilai ratarata masing-masing kelas kontrol sebesar 26,53 dan nilai rata-rata kelas eksperimen sebesar 25,71. Berdasarkan dari nilai rata-rata data pretest dari kedua kelas yang diperoleh, pengetahuan awal yang dimiliki kedua kelas sama karena tidak terdapat perbedaan nilai yang signifikan. Kemudian peneliti melakukan uji normalitas dan uji homogenitas pada nilai pretest yang diperoleh. Hasil uji normalitas pada tabel 4.3 diperoleh hasil pretest bersifat normal dengan nilai sig. $>0,05$. Begitu juga pada uji homogenitas, pada tabel 4.4 diperoleh bahwa hasil pretest untuk kedua kelas bersifat homogen. Berdasarkan uji normalitas dan uji homogenitas untuk kedua kelas yaitu kelas kontrol dan kelas eksperimen menyatakan bahwa kedua kelas memiliki keadaan dan kondisi yang sama.

Penerapan pembelajaran dengan model konvensional pada kelas XI MIPA 3 kurang melibatkan siswa, sehingga guru lebih berperan dalam proses pembelajaran dan guru mengharapkan siswa dapat memahami materi berdasarkan apa yang disampaikan oleh guru dengan memberikan beberapa soal di akhir pembelajaran sebagai tolak ukur pemahaman siswa terhadap materi yang sudah di sampaikan. Sebaliknya pada kelas XI MIPA 1 sebagai kelas eksperimen yang diberi perlakuan dengan menggunakan model pembelajaran kooperatif tipe think pair share, setiap siswa lebih dilibatkan langsung selama proses pembelajaran. Guru hanya mendampingi atau membimbing siswa selama proses pembelajaran.

Siswa di kelas kontrol memiliki keaktifan yang lebih kecil dibandingkan siswa di kelas eksperimen. Hal ini yang menunjukan perbedaan peningkatan hasil belajar kimia siswa di kelas kontrol yang tanpa perlakuan model pembelajaran kooperatif tipe think pair share dengan peningkatan hasil belajar kimia siswa di kelas eksperimen yang diberi perlakuan model pembelajaran kooperatif tipe think pair share. Dengan perbedaan langkah-langkah yang harus diterapkan pada kedua kelas baik kelas kontrol maupun kelas eksperimen, mengakibatkan perbedaan nilai hasil posttest yang diperoleh, dengan nilai terendah pada kelas kontrol sebesar 62 , nilai tertinggi sebesar 84 dan rata-rata kelas kontrol yang diperoleh sebesar 76,02 , sedangkan di kelas eksperimen diperoleh nilai terendah sebesar 72 dan nilai 
tertinggi sebesar 90 dengan nilai rata-rata kelas sebesar 78,07 . Perbedaan nilai yang diperoleh kedua kelas dapat terlihat dari nilai terendah, tertinggi, maupun rata-rata kelas dari kelas kontrol dan kelas eksperimen.Nilai yang diperoleh kelas eksperimen lebih tinggi dari nilai yang diperoleh dari kelas kontrol.

Setelah memberikan perlakuan, peneliti memberikan soal instrumen sebanyak 10 soal, yang diberikan sama dengan soal pada saat sebelum diberi perlakuan. Pemberian soal kepada kelas kontrol dan kelas eksperimen tersebut sebagai hasil akhir berupa nilai posttest untuk melihat tingkat pemahaman siswa setelah proses pembelajaran yang sudah diberi perlakuan dengan model pembelajaran think pair share maupun yang tanpa perlakuan model pembelajaran think pair share. Hasil nilai posttest yang diperoleh dikelas kontrol dengan nilai terendah sebesar 68 dan nilai tertinggi sebesar 84 dengan nilai rata-rata posttest kelas kontrol sebesar 76,02. Pada kelas eksperimen diperoleh nilai posttest terendah sebesar 72 dan nilai tertinggi sebesar 90 dengan nilai rata-rata posttest kelas eksperimen sebesar 78,07. Berdasarkan nilai posttest yang diperoleh dari kedua kelas, hasil belajar dari kelas eksperimen yang diberikan perlakuan model pembelajaran think pair share lebih tinggi dari kelas kontrol yang tidak diberi perlakuan model pembelajaran think pair share. Bila dilihat dari nilai rata-rata posttest kedua kelas, meskipun selisih nilai rata-rata kelas kontrol dan kelas eksperimen sebesar 2,05, kelas eksperimen lebih tinggi peningkatannya dari kelas kontrol terlihat dari pencapaian nilai terendah maupun nilai tertinggi yang diperoleh lebih tinggi dibandingkan kelas kontrol.

Selanjutnya ketika peneliti sudah mendapatkan nilai pretest dan posttest dari kedua kelas, peneliti melakukan uji hipotesis statistik untuk melihat peningkatan hasil belajar siswa dengan menggunakanmodel pembelajaran kooperatif tipe think pair share. Karena hasil pretest yang diperoleh normal dan homogen, maka dilakukan uji hipotesis parametrik. Oleh sebab itu peneliti melakukan uji hipotesis dengan menggunakan paired samples $t$ test. Berdasarkan hasil paired samples $t$ test, output nilai mean yang merupakan nilai selisih ratarata yang didapatkan dari rata-rata nilai pretest dan nilai posttest. Kelas kontrol memiliki selisih nilai rata-rata pretest dengan posttest sebesar 49,67 sedangkan kelas eksperimen memiliki selisih nilai rata-rata pretest dengan posttest sebesar 52,36 hal ini menunjukan bahwa selisih nilai rata-rata yang lebih besar adalah kelas eksperimen dibandingkan kelas kontrol. Selanjutnya terdapat perbedaan nilai standar deviasi yang diperoleh dari kedua kelas.Kriteria pengujian dilihat dari nilai $t$ dan dari nilai signifikan, diperoleh bahwa $t_{\text {hitung }}$ $(36,286)>t_{\text {tabel }}(2.00247)$ dan $p$-value $0,00<0,05$, hal ini menunjukan bahwa terdapat peningkatan hasil belajar kimia siswa dengan menggunakan model pembelajaran kooperatif tipe think pair share. 
Setelah mengetahui bahwa terdapat peningkatan hasil belajar kimia siswa, peneliti melakukan uji gain dengan rumus (nilai posttest-nilai pretest)/(100-nilai pretest). $N$-gain untuk melihat berapa besar peningkatan hasil belajarnya. Hasil yang diperoleh kelas kontrol tanpa model pembelajaran think pair share memperoleh skor gain 0,67 . Di kelas eksperimen yang diterapkan model pembelajaran think pair share memperoleh skor gain 0,70. Peningkatan dengan skor gain 0,70 sudah termasuk peningkatan dengan kategori tinggi namun tidak signifikan. Dalam uji gain, skor gain pada kelas kontrol termasuk kategori sedang karena $<0,70$, dan pada kelas eksperimen skor gain yang diperoleh sudah 0,70 maka terkategori tinggi. Meskipun selisih skor gain dari kelas kontrol dan kelas eksperimen sebesar 0,03, tetap dikatakan terjadi peningkatan hasil belajar kimia siswa ketika diberi perlakuan model pembelajaran think pair share. Faktor yang membuat skor gain atau tingkat peningkatan kelas kontrol dan kelas eksperimen selisih sedikit, dikarenakan pada saat diberi perlakuan di kelas eksperimen, waktu pada saat pembelajaran tidak sesuai dengan kegiatan pembelajaran pada RPP, pada tahap pengajuan soal, siswa masih membutuhkan waktu yang lebih banyak daripada waktu yang dipersiapkan di RPP sehingga siswa masih membutuhkan waktu untuk menganalisis soal yang diajukan.

Seperti pada tahap think di RPP hanya membutuhkan waktu 30 menit, namun siswa membutuhkan lebih dari 30 menit untuk berpikir. Pada tahap pair waktu yang sudah ditentukan adalah 45 menit, namun siswa juga masih membutuhkan waktu untuk berdiskusi dan menyatukan pendapat mengenai soal yang sudah mereka peroleh masing-masing. Faktor lainnya dikarenakan pembelajaran yang belum efesien namun siswa dikelas tetap harus belajar dan masih banyak siswa diluar kelas yang ribut saat pelajaran, bahkan adanya lomba poco-poco untuk perwakilan beberapa siswa di lapangan serta adanya masa pengenalan lingkungan sekolah (mpls) bagi siswa siswi murid baru sehingga terkadang fokus siswa teralihkan.Namun guru mengarahkan agar siswa tetap fokus terhadap soal yang sudah diberikan.

Selain melihat peningkatan hasil belajar kimia siswa, peneliti juga melihat keaktifan siswa selama proses pembelajaran berlangsung, dan sistem penilaian terlampir dalam lampiran RPP. Hasil penelitian dan pengamatan selama 4 kali pertemuan menemukan bahwa skor keaktifan dikelas eksperimen lebih tinggi dibandingkan skor keaktifan dikelas kontrol selama proses pembelajara berlangsung, yang terlampir di lampiran keaktifan siswa perkelas. Perbedaan keaktifan siswa dikelas eksperimen dikarenakan siswa lebih berperan aktif selama proses pembelajaran dengan menggunakan model pembelajara kooperatif tipe think pair share selama proses pembelajaran berlangsung dimulai dari berpikir dan menganalisis sendiri soal yang diberikan guru, lalu bekerjasama dengan teman 
kelompoknya, serta berbagi hasil diskusi yang sudah didiskusikan dengan teman kelompoknya, serta siswa dipacu untuk berani mempresentasikan hasil diskusinya dan teman yang lain dipacu untuk mendengarkan teman atau kelompok yang sedang memaparkan hasil diskusinya serta berani memberi tanggapan kepada mengenai pemaparan siswa dari kelompok lain.

\section{KESIMPULAN DAN SARAN}

Berdasarkan hasil pengolahan data serta pengujian hipotesis, dapat disimpulkan bahwa dengan paired sample $t$ test diperoleh t hitung sebesar 36,286 sedangkan t tabel (df $=57)=2.00247$ dan $p$ value $=0,00$ dengan signifikan 0,05 . Karena $t_{\text {hitung }}>t_{\text {tabel }}$ dan $p$ value $<$ 0,05 maka hal ini menunjukan bahwa terdapat peningkatan hasil belajar kimia siswa menggunakan Untuk peneliti selanjutnya, dapat menggunakan materi lain yang berbeda serta melakukan perbaikan dari penelitian sebelumnya. Model pembelajaran kooperatif tipe think pair share. Hasil belajar kimia siswa dengan menggunakan model pembelajaran kooperatif tipe think pair share diperoleh skor gain sebesar 0,70. Interpretasi peningkatan hasil belajar 0,70 termasuk ke dalam peningkatan kategori tinggi.

Berdasarkan kesimpulan diajukan beberapa saran sebagai berikut. Guru dapat menggunakan model pembelajaran kooperatif tipe think pair share dengan materi yang sesuai karakteristik model ini, dengan catatan, memperhatikan waktu pada saat pelaksanaan agar sesuai dengan waktu yang ada di RPP sehingga hasil yang diperoleh lebih maksimal. Guru sebaiknya memberikan informasi mengenai model pembelajaran yang akan digunakan selama proses pembelajaran berlangsung, sehingga siswa memahami apa yang harus di lakukan selama proses pembelajaran.

\section{ACUAN PUSTAKA}

Emda, I.A. (2014). Penerapan Model Pembelajaran Kooperatif Tipe TPS di SMA Negeri 12 Banda Aceh. Lantanida Journal 1(1):1-6.

Dimyati. (2015). Belajar \& Pembelajaran. Jakarta: Rineka Cipta

Fajaryanti, D.E., Vanny M.A., Tiwow., dan Rahman.N. (2014). Penggunaan Model Pembelajaran Kooperatif Tipe Think Pair Share (TPS) Pada Pokok Bahasan Struktur Atom Untuk Meningkatkan Hasil Belajar Siswa Kelas X SMA Negeri 2 Palu. Jurnal Akademika Kimia 3(3): 129-134

Harnanto, A., dan Ruminten (2009). Kimia untuk SMA/MA Kelas X. Jakarta: Seti-Aji

Jannah, R., Saputro, A.N.C., Yamtinah, S. (2014). Penerapan Model Pembelajaran Think Pair Share (TPS) disertai Buku Saku untuk Meningkatkan Aktivitas dan Prestasi 
Belajar Kimia Pada Materi Minyak Bumi Kelas X SMA Negeri Gondangrejo Tahun Pelajaran 2012/2013. Jurnal Pendidikan Kimia (JPK) 2(2):1-5

Kementrian Pendidikan dan Kebudayaan. (2017). Rekap Hasil Ujian Nasional(UN) Tingkat Sekolah. https://puspendik.kemdikbud.go.id/hasil-un/2018/03/07.

Kuswati, T.M., Ernavita, Ratih, Marwati, E. (2013). Konsep dan Penerapan Kimia SMA/MA Kelas XI. Jakarta: PT Bumi Aksara

Latief, H., Rohmat, D., dan Ningrum, E. (2014). Pengaruh Pembelajaran Kontekstual Terhadap Hasil Belajar. Jurnal Gea 14(1)

Ristiyani, E., Bahriah, E.S. (2016). Analisis Kesulitan Belajar Kimia Siswa di SMAN X Kota Tanggerang Selatan. Jurnal Penelitian dan Pembelajaran IPA 2(1): 18-29

Rusman. (2017). Berorientasi Standar Proses Pendidikan. Jakarta: Kencana

Rusmono. (2017). Problem Based Learning. Bogor: Penerbit Ghalia Indonesia

Setyosari, H.P. (2012). Metode Penelitian Pendidikan dan Pengembangan edisi kedua. Jakarta: Kencana Prenada Media Group.

Shoimin, A. (2014). 68 Model Pembelajaran Inovatif dalam Kurikulum 2013. Yogykarta: Arruzz Media.

Slameto. (2010). Belajar dan Faktor-Faktor yang Mempengaruhinya edisi revisi. Jakarta: Rineka Cipta.

Sudarmo, U. (2013). Kimia untuk SMA/MA Kelas XI. Jakarta: Erlangga.

Sudjana, N. (2009). Penilaian Hasil Proses Belajar Mengajar. Bandung: Remaja Rosdakarya.

Sugiarto, D., dan Sumarsono, P., (2014).The Implementation of Think-Pair-Share Model. International Journal of English and Education3(3): 1-10

Sugiyono, (2015). Statistika Untuk Penelitian. Bandung: Alfabeta.

Suhardi, Y. (2018). Penerapan Model Pembelajaran Kooperatif tipe Think Pair Share (TPS) untuk meningkatkan hasil belajar peserta didik pada mata pelajaran kimia tentang termokimia di kelas XI MIPA-SMA Negeri 7 Kota Bogor. Jurnal Educate 3(1): 52-72

Surraya, L., Subagia, I.W., dan Tika, I.N. (2014) Pengaruh Model Pembelajaran Think Pair Share Terhadap Hasil Belajar IPA ditinjau dari Keterampilan Berpikir Kritis Siswa. eJournal Program Pascasarjana Universitas Pendidikan Ganeshs Program Studi IPA 4(1): 1-11

Trianto.(2010). Mendesain Model Pembelajaran Inovatif-Progresif. Jakarta: Kencana.

Wardana, L.W., Edoh., Harwida, G. (2017). Implementation Of Collaborative Learning Model Thingking Pair Share (TPS) And Arias To Improve Student Learning Results In Entrepreneurship Subjects. International Journal Of Academic Research In Business and Social Sciences 7(7): 1-10 
JDP Volume 12, Nomor 1, April 2019: 41-54 